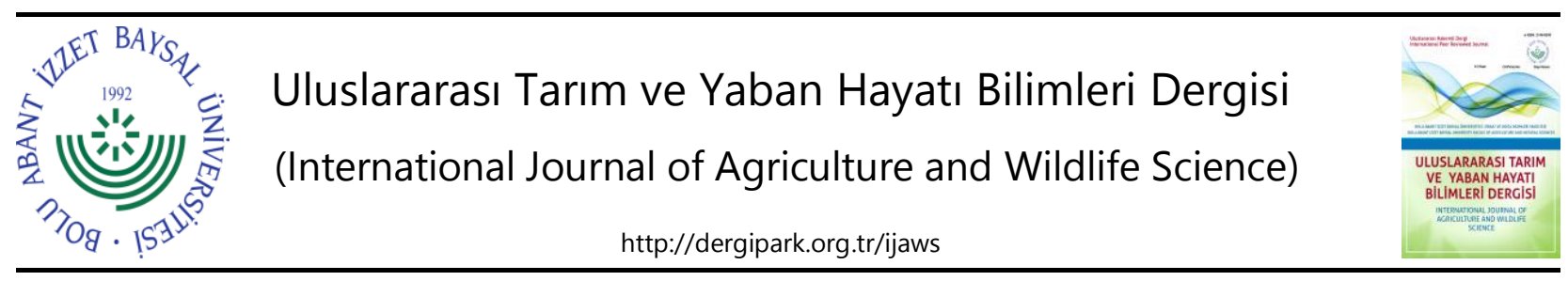

Araştırma Makalesi

\title{
Yulafın (Avena sativa L.) Verim ve Kalitesine Çinko Uygulaması ve Ekim Zamanının Etkileri
}

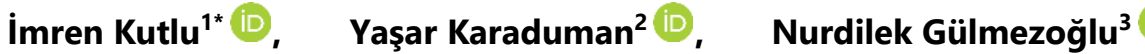 \\ ${ }^{1}$ Eskişehir Osmangazi Üniversitesi, Ziraat Fakültesi, Biyosistem Mühendisliği Bölümü, Eskişehir \\ ${ }^{2}$ Eskişehir Osmangazi Üniversitesi, Ziraat Fakültesi, Gıda Mühendisliği Bölümü, Eskişehir \\ ${ }^{3}$ Eskişehir Osmangazi Üniversitesi, Ziraat Fakültesi, Toprak Bilimi ve Bitki Besleme Bölümü, Eskişehir \\ Geliş tarihi (Received): 06.11.2020 Kabul tarihi (Accepted): 08.02.2021
}

\section{Anahtar kelimeler:}

$\beta$-glukan, bin tane ağırlığı, kışlık ve yazlık ekim, mikro elementler, tanede $\mathrm{Zn}$.
*Sorumlu yazar ikutlu@ogu.edu.tr
Özet. Bu çalışmada, çinko (Zn) uygulamalarının kışlık ve yazlık ekim zamanlarında ekilen yerel yulaf genotiplerinin verim performansı, tane kalite özellikleri (protein, $\beta$-glukan, ADF ve NDF) ve mikro element ( $\mathrm{Zn}, \mathrm{Fe}, \mathrm{Cu}$ ve $\mathrm{Mn}$ ) konsantrasyonu üzerine etkilerini belirlemek amaçlanmıştır. Deneme üç tekerrürlü olarak bölünmüş parseller deneme deseninde arazi koşullarında oluşturulmuştur. Ekim zamanı ana parsellere, $\mathrm{Zn}$ uygulamaları $\left(0,5\right.$ ve $\left.10 \mathrm{~kg} \mathrm{ha}^{-1}\right)$ alt parsellere ve genotipler alt alt parsellere yerleştirilmiştir. Çinko uygulamaları, hem kışlık hem de yazlık ekimlerde, genotiplerin tane verimini, $\beta$-glukan, ADF, NDF ve mikroelement konsantrasyonlarını artırmıştır. Tane protein içeriği $\mathrm{Zn}$ uygulamaları ile azalış göstermiştir. Yulaf tanelerinin $\mathrm{Zn}$ konsantrasyonu, $\beta$-glukan, $\mathrm{Cu}$ ve $\mathrm{Mn}$ ile pozitif; protein, $\mathrm{Fe}$ ve $\mathrm{Cu}$ ile negatif bir korelasyon göstermiştir. Elde edilen verilere göre yulaf bitkilerine Zn uygulanmasıyla, kışlık ve yazlık ekimde verim performansının artırılabileceğini ve kalitesinin iyileştirilebileceği görülmüştür. Kışlık ekimde yulafın incelenen tane kalitesi özellikleri ve mikroelement konsantrasyonları yazlık ekimden daha yüksek olarak belirlenmiştir. Bu nedenle, ülkemizde yazlık olarak yetiştirilen yulaf bitkilerinin, kışı çok sert geçmeyen iklim koşullarına sahip bölgelerde, kışlık olarak da yetiştirilebilmesinin tane kalitesini olumlu etkileyeceği sonucuna varılmıştır. Aynı zamanda yulaf bitkisinin tane $\mathrm{Zn}$ içeriğinin artıııması ile insan ve hayvan beslenmesindeki etkinliği de artmış olacaktır.

\section{The Effects of Zinc Application and Planting Time on Yield and Quality of Oats (Avena sativa L.)}

\section{Keywords:}

$\beta$-glukan, thousand kernel weight, winter and spring sowing, micro elements, $\mathrm{Zn}$ in grain

\begin{abstract}
The aim of the study is to determine the effects of zinc $(\mathrm{Zn})$ applications on yield performance, grain quality characteristics (protein, B-glucan, ADF, NDF) and micro element (Zn, Fe, $\mathrm{Cu}, \mathrm{Mn}$ ) concentration of local oat genotypes planted in winter and spring sowing. The experiment was created in three replications in a split plot pattern under field conditions. Sowing time was placed in main plots, $\mathrm{Zn}$ application rates $\left(0,5\right.$ and $\left.10 \mathrm{~kg} \mathrm{ha}^{-1}\right)$ in sub plots and genotypes in subsub plots. Zinc applications increased in grain yield, $\beta$-glucan, ADF, NDF and micro element concentration of genotypes at winter and spring sowing. On the other hand, grain protein content decreased with $\mathrm{Zn}$ applications. The $\mathrm{Zn}$ concentration of the oat grains showed a positive correlation with B-glucan, $\mathrm{Cu}$ and $\mathrm{Mn}$, and a negative correlation with protein, $\mathrm{Fe}$ and $\mathrm{Cu}$. The results showed that by applying $\mathrm{Zn}$ to oat plants, the yield performance and quality can be improved in winter and spring planting. The overall performance of winter cultivation was determined to be higher than spring cultivation. Therefore, it was concluded that growing oat plants, which are typically grown in the spring in our country, under zones which not too harsh winter conditions, can positively affect the grain quality. In addition, by increasing the grain $\mathrm{Zn}$ content of the oat plant, its effectiveness in human and animal nutrition will be increased.
\end{abstract}




\section{GíRiş}

Yulaf (Avena sativa L.), daha çok hayvan yemi olarak tercih edilmesine rağmen son yıllarda insan beslenmesinde kullanımı artan bir tahıl olmuştur (Kahraman ve ark., 2019). Bisküvi, kahvaltılık gevrekler ve bebek mamaları başta olmak üzere, son yıllarda sağlıklı beslenmede oldukça önemli bir potansiyeli olduğu düşünülen yulaflı gıdalar, iyi tat, üstün besleme özellikleri ve vücuttaki metabolik değişiklikleri uyaran zengin bir protein (globulinler), $\beta$-glukan, vitamin ve mineral kaynağı olması nedeniyle tahıllar arasında farkı dikkat çekici hale gelmiştir (Kaur ve ark., 2019). Bu sebeplerle, yulaf, hem bilimsel araştırmaların ilgi odağı olmakta hem de bilinen sağlık yararları nedeniyle gıda endüstrisinde bir hammadde olarak gün geçtikçe popüler hale gelmektedir. Bunlara ek olarak, yulaf, prolamin bileşeni, fenolik bileşikleri ve aminoasit dizilimi nedeniyle ciddi ilgi görmekte, çölyak hastaları için glütensiz gıda ürünü geliştirmede yulaf ununun kullanılması nedeniyle de ilgi çekici olmaktadır. Üstün besleyici özellikleri ve özellikle de protein, lif miktarı ve mineral maddeler açısından zengin olması, yulaf tanesinin hayvan beslenmesinde de vazgeçilmez olmasını sağlamaktadır (Stevens ve ark., 2004).

Dünyada yulaf ekim alanı 9.72 milyon ha ve üretimi 21.9 milyon ton, Türkiye'de ise ekim alanı 109.8 bin ha ve üretimi 265 bin tondur (Anonim, 2020). Bu miktarlar mısır, buğday, çavdar veya arpa gibi diğer tahı ürünlerine göre önemli ölçüde daha azdır (Daryanto ve ark., 2016). Bu durum yulafın diğer tahıllara kıyasla daha düşük verim performansına sahip olmasından kaynaklanmaktadır (Brand ve ark., 2003). Yulafın veriminin arttıııması, çeşit geliştirme yanında, bitkilerin dengeli ve yeterli bir şekilde beslenmeleri, diğer kültürel uygulamalar ve ekiminin uygun zamanda yapılması ile mümkündür. Özellikle Orta Anadolu Bölgesi gibi yaz döneminin kurak geçtiği bölgelerde kışıık olarak sonbaharda ekilen tohumların çimlenerek kışı fide halinde geçirmeleri, takip eden sezonda erkenden büyümeye başlaması, soğuğa tolerans sağlaması ve yüksek verim açısından önemlidir. Genellikle kışık ekilen tahıllar yazlık ekilenlere göre daha verimli olmaktadır. Kurağa ve soğuğa çok hassas olması sebebiyle, ülkemiz koşullarında kışlık ekimi yapılan yerlerde soğuktan önemli ölçüde zarar gördüğü için Orta Anadolu Bölgesi'nde yulaf ekimi yalnızca yazlık olarak yapılmaktadır. Ancak, yazlık ekimlerde kısa vejetasyon süresi, ilkbahardaki düzensiz ve yetersiz yağışlar yulaf verimini olumsuz yönde etkilemektedir. Bu nedenle, geçimini büyük ölçüde tahıldan sağlayan Orta Anadolu Bölgesi üreticileri tarafından yulaf üretimi tercih edilmemektedir.

Yulaf, yüksek yağış alan yerlerde ve asitli topraklarda diğer tahıllara göre daha iyi yetişir, hastalıklara karşı dirençlidir ve kök sisteminin kuvvetli olması sebebiyle toprakta mevcut besin maddelerinden daha çok faydalanabilmektedir (Givens ve ark., 2004). Ülkemiz tarım alanlarında, genellikle azot, fosfor ve potasyum içeren gübreler yeterli düzeyde ve düzenli olarak kullanılmasına rağmen, demir $(\mathrm{Fe})$, mangan $(\mathrm{Mn})$, bakır $(\mathrm{Cu})$ ve çinko (Zn) gibi mikroelementlerin kullanımı sınırlıdır. Bu mikro besinlerin herhangi birinin eksik ya da fazla olması bitkide olumsuz etkiler ortaya çıkartmaktadır. Mikroelementler içerisinde $\mathrm{Zn}$ öne çıkan bitki besin elementlerinden bir tanesidir ve eksikliği yaygın görülen mikroelementlerden biridir (Eyüpoğlu ve ark., 1994). Çinko noksanlığına karşı tahıl türlerinin ve aynı türün çeşitleri arasında önemli farklılıkların olduğu belirlenmiştir. Yeşil aksamdaki semptomların şiddetine ve kuru madde veya tane verimindeki azalmaya göre, tahıl türleri içerisinde $\mathrm{Zn}$ noksanlığına dayanıklılığı en fazla olanlar çavdar ve tritikale iken yulaf ve makarnalık buğdayın Zn noksanlığından önemli ölçüde etkilendiği saptanmıştır (Çakmak ve ark., 1998). Gıda, tarım ve sanayi alanlarında giderek artan yulaf talebini karşılayabilmek ve aynı zamanda kısıtlı tarım alanlarından yüksek verimli ve kaliteli ürün elde etmek için yulafın kışlık olarak ekilmesine de ihtiyaç duyulmaktadır. Bu çalışma ile kışlık ve yazlık ekilerek, artan oranda Zn (0, $5,10 \mathrm{~kg} \mathrm{Zn} \mathrm{ha}^{-1}$ ) uygulamasının, Eskişehir yöresinde yetiştirilen iki yerel yulaf genotipinin tane verimi, kalitesi ve mikroelement içeriklerine etkilerini belirlemek amaçlanmıştır.

\section{MATERYAL VE METOT}

\section{Deneme Yerinin Özellikleri}

Deneme, 2017/2018 yetiştirme sezonunda Eskişehir Osmangazi Üniversitesi Ziraat Fakültesi deneme tarlalarında kurulmuştur. Deneme alanının iklim verileri (aylık toplam yağış, ortalama sıcaklık ve bağı nem) ekim sezonu (2017/2018) ve uzun yıllar (1939-2017) olarak Şekil 1'de verilmiştir. Ekim sezonu boyunca toplam yağış, ortalama sıcaklık ve nem değerleri uzun yıllar ortalamasından daha yüksek olmuştur. Özellikle kış ayları bölgenin tipik ikliminden farkıı bir şekilde ve mevsim normallerine göre daha sıcak geçmiş̧ir. Deneme alanı toprakları hafif alkalin, tuzsuz ve killi tın bünyeye sahiptir. Organik madde, $\mathrm{Mn}$ ve $\mathrm{Zn}$ içerikleri düşükken $\mathrm{K}, \mathrm{Fe}, \mathrm{P}$, Cu ve kireç içerikleri yeterli seviyede belirlenmiştir (Çizelge 1). 


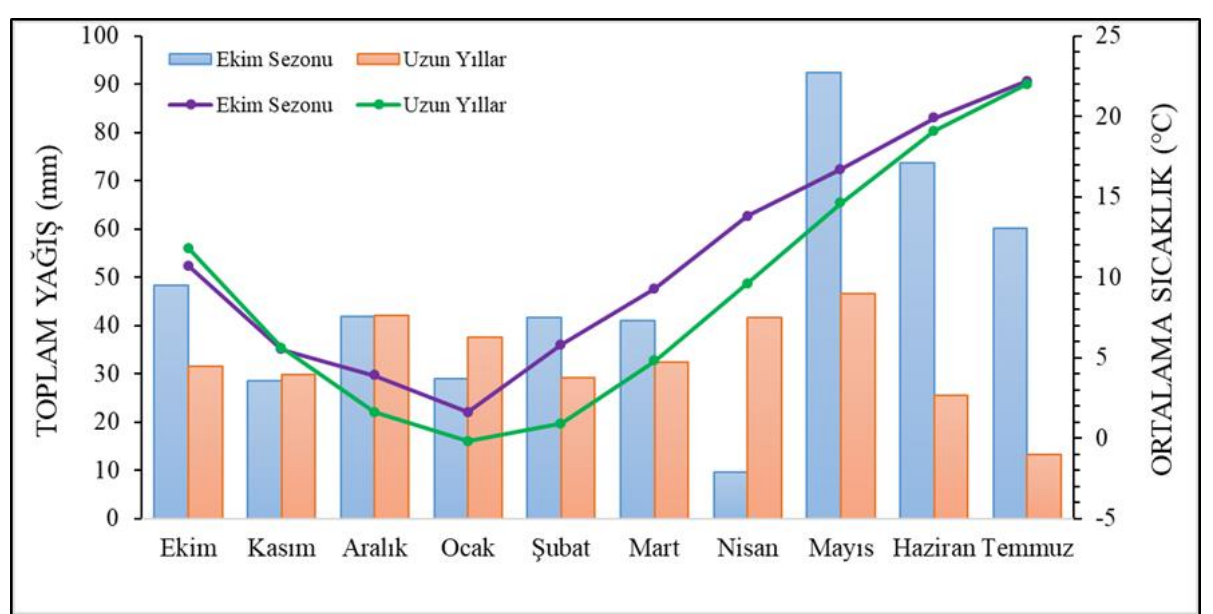

Şekil 1. Deneme yerinin iklim özellikleri.

Figure 1. Climatic characteristics of experimental area.

Çizelge 1. Deneme alanı topraklarının bazı fiziksel ve kimyasal özellikleri.

Table 1. Some physical and chemical characteristics of experimental soil.

\begin{tabular}{ccccccccccc}
\hline pH & Bünye & $\begin{array}{c}\text { Tuz } \\
(\%)\end{array}$ & $\begin{array}{c}\text { Kireç } \\
(\%)\end{array}$ & $\begin{array}{c}\text { Organik madde } \\
(\%)\end{array}$ & $\begin{array}{c}\mathbf{P}_{2} \mathbf{O}_{5} \\
\left(\mathbf{k g ~ h a}^{-1}\right)\end{array}$ & $\begin{array}{c}\mathbf{K}_{2} \mathbf{O} \\
\left(\mathbf{k g ~ h a}^{-1}\right)\end{array}$ & $\begin{array}{c}\mathbf{F e} \\
\left(\mathbf{m g ~ k g}^{-1}\right)\end{array}$ & $\begin{array}{c}\mathbf{M n} \\
\left(\mathbf{m g ~ k g}^{-1}\right)\end{array}$ & $\begin{array}{c}\mathbf{Z n} \\
\left(\mathbf{m g ~ k g}^{-1}\right)\end{array}$ & $\begin{array}{c}\mathrm{Cu} \\
\left(\mathbf{m g ~ k g}^{-1}\right)\end{array}$ \\
\hline 8,1 & Killi tin & 0.013 & 7.1 & 0.94 & 64.7 & 5651 & 6.1 & 10.5 & 0.87 & 2.1 \\
\hline
\end{tabular}

\section{Deneme Materyali ve Ekim Deseni}

Denemede materyal olarak, Eskişehir tahı üreticilerinden temin edilen iki yerel yulaf popülasyonu kullanılmıştır. Yulaf tohumları, kışlık olarak Ekim ve yazlık olarak Mart ayında, bölünmüş parseller deneme desenine göre $4 \mathrm{~m}$ uzunluğundaki 6 sıralı parsellere 3 tekerrürlü olarak deneme mibzeri ile ekilmişlerdir. Parsellerde sıra arası $20 \mathrm{~cm}$ ve parseller arası mesafe 2 m olarak ayarlanmıştır. Toprak analizinden sonra bitkilere $12 \mathrm{~kg} \mathrm{da}^{-1}$ azot ve $8 \mathrm{~kg} \mathrm{da}^{-1}$ $\mathrm{P}_{2} \mathrm{O}_{5}$ olacak şekilde diamonyum fosfat (18-46-0) ve amonyum sülfat (\%20.5 N) gübreleri uygulanmıs, fosforun tamamı ekimle birlikte, azotun yarısı ekimle diğer yarısı ise kardeşlenme döneminde verilmiştir. Sapa kalkma ve çiçeklenme döneminde iki defa takviye sulama yapılmıştır.

Çinko uygulamasında, Cakmak ve ark. (1998) tarafından Orta Anadolu Bölgesi Zn eksik topraklar için önerilen $5 \mathrm{~kg} \mathrm{Zn} \mathrm{ha-1}$ optimum dozu referans olarak alınmış ve her iki ekim döneminde de $\mathrm{ZnSO}_{4} .7 \mathrm{H}_{2} \mathrm{O}$ olarak 0 (kontrol), $5 \mathrm{~kg} \mathrm{Zn} \mathrm{ha}^{-1}$ ve $10 \mathrm{~kg} \mathrm{Zn} \mathrm{ha-1}$ olmak üzere 3 doz halinde uygulama yapılmıştır.

\section{Gözlem ve Ölçümler}

Parsel verimi, her parselden hasat ve harman edilen bitkilerden elde edilen tohumlar tartılıp ortalaması alınarak gram olarak ölçülen değerler $\mathrm{kg} \mathrm{da}^{-1}$ olarak hesaplanmıştır. Elde edilen tanelerde protein ve $\beta$-glukan oranı, asit deterjan fiber (ADF), nötral deterjan fiber (NDF) ve mikro element içeriklerinin belirlenmesi için laboratuvar tipi un değirmeninde öğütülerek analizler yapılmıştır. Tane protein içeriği ve $\beta$-glukan oranı tam tane unundan (kırma) Near-Infrared Spektrokopi (NIR 6500, Foss, Hillerød, Denmark) cihazı ile belirlenmiş, olup cihazın tane protein oranı ve $\beta$-glukan oranı için sırasıyla AACC metot 46-19.01 ve 32-23.01 'e göre kalibrasyonu yapılmıştır (AACCI, 2010). ADF ve NDF oranları Ankom Fiber Analiz Cihazı (Fiber Analyser, ANKOM marka, A220 model) kullanılarak belirlenmiştir (Van Soest ve ark., 1991).

Tanelerde $\mathrm{Zn}, \mathrm{Fe}, \mathrm{Cu}$ ve $\mathrm{Mn}$ konsantrasyonlarını belirlemek için öğütülmüş örneklerden $0.2 \mathrm{~g}$ tartılıp, mikrodalga cihazında (CEM Mars6) yaş yakma metoduna göre $\mathrm{H}_{2} \mathrm{O}_{2}-\mathrm{HNO}_{3}$ (3:2) asit karışımında yakılıp, süzülmüş ve saf su ile $20 \mathrm{ml}$ son hacme tamamlanmıştır. Süzüklerdeki $\mathrm{Zn}, \mathrm{Fe}, \mathrm{Cu}$ ve $\mathrm{Mn}$ konsantrasyonları atomik absorbsiyon spektrofotometre cihazı (Analytik Jena, novAA 800) ile belirlenmiştir (Soil Survey Laboratory Methods Manuel, 2004). Gerçekleştirilen mineral analizlerinin doğrulaması aynı analitik yöntemler ile bir referans örneğinin (domates yaprağı; 1573a-NIST, Gaithersburg, MD, ABD) element içerikleri belirlenerek yapılmıştır. 


\section{BULGULAR VE TARTIŞMA}

\section{Tane Verimi ve Kalite Özellikleri}

Tane verimi, bin tane ağırlığı, tane protein içeriği, $\beta$-glukan içeriği, ADF, NDF oranları özelliklerine ekim zamanı ve $Z n$ uygulamaları ve genotipin etkileri önemli bulunurken, "ekim zamanı $\times Z n$ ", " $Z n \times$ genotip" ve "ekim zamanı $\times \mathrm{Zn} \times$ genotip" interaksiyonları verim ve bin tane özellikleri açısından önemsiz bulunmuştur (Çizelge 2).

Tane verimleri açısından en yüksek değer kışıık ekimde $10 \mathrm{~kg} \mathrm{Zn} \mathrm{ha}^{-1}$ uygulamasından ve Yerel Genotip-1'den elde edilmiştir (Çizelge 3). Kışlık ekimde tane veriminin yüksekliği artan vejetasyon süresi ile birlikte tane dolum süresinin uzamasına bağı olarak bitkilerin topraktaki su ve besin elementlerini daha etkin biçimde kullanmasından kaynaklandığı düşünülmektedir. Her iki ekim döneminde de Zn dozlarının artışına bağlı olarak tane verimleri yükselmiştir. Yapılan pek çok çalışmada Zn gübrelemesinin tahıllarda tane verimini artırırı̆ı̆ı belirlenmiştir (Ghasal ve ark., 2017; Liu ve ark., 2017; Kutlu ve Gülmezoğlu, 2020; Yılmaz ve Sonkaya, 2020).

Çizelge 2. Incelenen karakterlerin varyans analizi.

Table 2. ANOVA of examined characters.

\begin{tabular}{|c|c|c|c|c|c|c|c|c|c|c|}
\hline $\begin{array}{l}\text { Varyasyon } \\
\text { Kaynağı }\end{array}$ & $\begin{array}{l}\text { Tane } \\
\text { Verimi }\end{array}$ & $\begin{array}{l}\text { Bin Tane } \\
\text { Ağırlığı }\end{array}$ & $\begin{array}{l}\text { Protein } \\
\text { İçeriği }\end{array}$ & $\beta$-Glukan & ADF & NDF & Zn & $\mathrm{Fe}$ & $\mathrm{Cu}$ & Mn \\
\hline $\mathrm{EZ}$ & $24.86^{\star \star}$ & $58.94^{\star *}$ & $422.56^{\star \star}$ & $3666.12^{\star \star}$ & $4578.89^{\star \star}$ & $20486.95^{\star *}$ & $28.42^{\star \star}$ & $1664.15^{\star \star}$ & $264.31^{\star \star}$ & $199.74^{\star \star}$ \\
\hline $\mathrm{Zn}$ & $64.84^{* *}$ & $19.74^{* *}$ & $65716.26^{* *}$ & $10665.67^{\star *}$ & $32331.34^{* *}$ & $44132.90^{\star *}$ & $61.50^{* \star}$ & $75.99^{* \star}$ & $21.06^{* *}$ & $379.07^{\star *}$ \\
\hline Genotip & $5.94^{*}$ & $12.39 * *$ & $16746.10^{\star \star}$ & $768.10^{* *}$ & $9617.49^{* *}$ & $11755.94^{* \star}$ & 0.19 & $16.74^{* *}$ & 3.90 & $200.40^{* *}$ \\
\hline $\mathrm{EZ} \times \mathrm{Zn}$ & 0.87 & 0.38 & $15627.63^{* *}$ & $1132.69^{* *}$ & $44776.13^{* *}$ & $13967.21^{\star \star}$ & $22.56^{\star *}$ & 0.22 & 0.36 & $41.93^{* *}$ \\
\hline$E Z \times G$ & $15.94^{\star *}$ & $6.98^{* \star}$ & $92.02^{* *}$ & $9947.52^{\star *}$ & $50876.50^{* *}$ & $23566.95^{* *}$ & 0.08 & $5.19^{\star}$ & $4.28^{*}$ & $25.70^{* *}$ \\
\hline$Z n \times G$ & 2.28 & 1.08 & $2440.20^{* *}$ & $406.69^{* *}$ & $17740.17^{* *}$ & $3888.74^{* \star}$ & $3.07^{\star \star}$ & $5.81^{* \star}$ & 0.69 & 3.05 \\
\hline$E Z \times Z n \times G$ & 0.81 & 0.31 & $2565.53^{* *}$ & $6917.13^{\star *}$ & $70735.65^{* *}$ & $24135.61^{* *}$ & 0.66 & $7.37^{\star \star}$ & 3.02 & $4.69^{*}$ \\
\hline CV (\%) & 26.10 & 17.63 & 5.37 & 8.67 & 3.96 & 2.58 & 23.49 & 23.33 & 38.50 & 7.08 \\
\hline
\end{tabular}

${ }^{*} \mathrm{P} \leq 0.05,{ }^{* * P} \leq 0.01$, EZ: Ekim Zamanı, Zn: Çinko, G: Genotip.

Genotipik ve çevresel koşulların (iklim, toprak, gübreleme vb. yetiştirme tekniği uygulamaları) etkisinde olan bin tane ağırlığının yüksek olması hayvan beslenmesinde enerji değeri ve insan beslenmesinde son kullanım özellikleri bakımından önemlidir (Mut ve ark., 2018). Çalışmamızda artan Zn dozları ile her iki genotipinde kışlık ekimde vejetasyon süresinin uzamasına bağlı olarak bin tane ağılıkları artmış ve bu artış tane verimindeki yükselme ile desteklenmiştir (Çizelge 3). Yerel Genotip-2'nin bin tane ağırlığı Yerel Genotip-1'e göre daha yüksek bulunmuştur. En yükssek bin tane ağırlığı da $10 \mathrm{~kg} \mathrm{Zn} \mathrm{ha-1} \mathrm{uygulamasından} \mathrm{elde} \mathrm{edilmiştir.} \mathrm{Çinko} \mathrm{gübrelemesinin}$ bin tane ağırlığını arttırdığı Barut ve ark. (2017) ve Yılmaz ve Sonkaya (2020) tarafından yapılan çalışmalarla da desteklenmiştir.

Yulaf tanesinin tane protein oranının yüksek olması istenir ve yulaf tanesi genellikle ortalama \%11-15 arasında protein içerir (Rodehutscord ve ark.,2016). Çalışmada her iki yerel genotipte de hem kışlık hem de yazlık ekim zamanında Zn uygulamaları ile tane protein oranları azalış göstermiştir. Çinko uygulaması ile protein oranında meydana gelen bu azalış vejetasyon süresinin uzamasına bağlı olarak nişasta birikiminin artması, artan tane ağırlığı ve bunun sonucunda tanede meydana gelen seyrelme etkisinden kaynaklanmıştır. Ekim zamanlarının tane protein oranı üzerine belirgin etkisi olmamakla birlikte kışlık ekimde daha yüksektir. En yüksek tane protein oranı kışlık ekimde Yerel Genotip-1ve Zn uygulaması yapılmadığında elde edilmiştir (Çizelge 3). Çalışmamızı destekler şekilde Bagci ve ark. (2007) da çalışmalarında Zn uygulamasının tane protein oranını azalttığını bulurken, Mishra (2012) ve Akgün ve ark. (2016) Zn gübrelemesinin protein içeriğini olumlu etkilediğini bulmuşlardır.

Yulaf tanesinin alöron ve endosperminde \%6-9 oranında $\beta$-glukan bulunmaktadır (Kaur ve ark., 2019). Hücre duvarlarının önemli bir glikoz polimerleri olan $\beta$-glukan viskoz yapıda bir çözünür bir diyet lifidir. Yulaf tanesindeki $\beta$-glukan viskos yapıda olduğundan ince bağırsakta glikoz emilimini geciktirirken kolestrol emilimini baskılar, yemek sonrasında kanda glukoz ve insülin seviyelerinin azaltılması ve kolesterolün kontrolünü sağlar (Ames ve ark., 2018), kalp-damar hastalıkları, obezite ve diyabet hastalığının önlenmesi, tedavisi ve yönetiminde oldukça faydalıdır (Bozbulut ve Sanlıer, 2019). Bu özellikleri nedeni ile insan beslenmesinde $\beta$-glukan içeriğinin yüksek olması arzu edilmektedir. Çalışmamızda her iki genotipte de kışlık ekimde ve Zn uygulamasıyla $\beta$-glukan oranları yükselmiştir (Çizelge 3). En yüksek $\beta$-glukan oranı kışlık ekimde $10 \mathrm{~kg} \mathrm{Zn} \mathrm{ha-1}$ dozunda Yerel Genotip-2'den elde edilirken, en düşük olarak yazlık ekimde $Z n$ uygulaması yapılmayan Yerel Genotip-1'de saptanmıştır. $\beta$-glukan oranında $5 \mathrm{~kg} \mathrm{Zn} \mathrm{ha}^{-1}$ dozu ile $10 \mathrm{~kg} \mathrm{Zn} \mathrm{ha}^{-1}$ dozu arasında belirgin bir farklılık gözlemlenmemiştir. Kışlık ekimde Yerel Genotip-1 5 kg Zn ha-1 dozunda daha yüksek $\beta$-glukan oranına sahip olurken, yazlık ekimde Yerel Genotip- 
$25 \mathrm{~kg} \mathrm{Zn} \mathrm{ha}{ }^{-1}$ dozunda aynı tepkiyi göstermiş ve $10 \mathrm{~kg} \mathrm{Zn} \mathrm{ha}^{-1}$ dozunda azalış meydana gelmiştir. Protein oranının aksine tanede $\beta$-glukan oranının seyreltme etkisinde olmadığı ve $\mathrm{Zn}$ uygulamasından olumlu etkilendiği söylenebilir.

Çizelge 3. Verim ve kalite özelliklerinin ekim zamanı, Zn uygulamaları ve genotiplere göre değişimi.

Table 3. The change of yield and quality characteristics of oats according to sowing time, $\mathrm{Zn}$ applications and genotypes.

\begin{tabular}{|c|c|c|c|c|c|c|c|c|}
\hline $\begin{array}{l}\text { Ekim } \\
\text { zamanı }\end{array}$ & Genotipler & $\begin{array}{l}\text { Zn } \\
\text { uygulaması } \\
\left(\mathbf{k g ~ h a}^{-1}\right)\end{array}$ & $\begin{array}{l}\text { Tane } \\
\text { verimi } \\
\left(\mathbf{k g ~ d a}^{-1}\right)\end{array}$ & $\begin{array}{l}\text { Bin tane } \\
\text { ağırlığı } \\
\text { (g) }\end{array}$ & $\begin{array}{l}\text { Protein } \\
\text { (\%) }\end{array}$ & $\begin{array}{l}\beta \text {-glukan } \\
\text { (\%) }\end{array}$ & $\begin{array}{l}\text { ADF } \\
(\%)\end{array}$ & $\begin{array}{l}\text { NDF } \\
\text { (\%) }\end{array}$ \\
\hline \multirow{6}{*}{ Kışlık } & \multirow{3}{*}{ Yerel Genotip-1 } & 0 & 311.7 cde & $25.16 c-f$ & $12.96 \mathrm{a}$ & $3.95 \mathrm{~h}$ & $17.15 \mathrm{k}$ & $34.53 \mathrm{~h}$ \\
\hline & & 5 & $420.8 \mathrm{ab}$ & 27.77 b-e & $12.03 \mathrm{c}$ & $4.34 \mathrm{~d}$ & $18.62 \mathrm{~d}$ & $34.76 \mathrm{~g}$ \\
\hline & & 10 & $506.7 \mathrm{a}$ & $31.86 a b c$ & $10.74 \mathrm{j}$ & $4.07 \mathrm{f}$ & $17.72 \mathrm{~h}$ & $33.79 \mathrm{j}$ \\
\hline & \multirow{3}{*}{ Yerel Genotip-2 } & 0 & $254.2 \mathrm{de}$ & 31.28 a-d & $12.36 \mathrm{~b}$ & $3.85 j$ & $19.59 \mathrm{a}$ & $36.41 \mathrm{a}$ \\
\hline & & 5 & $343.3 \mathrm{bcd}$ & $32.96 \mathrm{ab}$ & $11.33 \mathrm{~g}$ & $4.66 \mathrm{~b}$ & $18.55 \mathrm{e}$ & $35.06 \mathrm{e}$ \\
\hline & & 10 & $405.8 \mathrm{abc}$ & 35.29 a & $10.85 \mathrm{i}$ & $5.05 \mathrm{a}$ & $17.56 \mathrm{i}$ & $34.56 \mathrm{~h}$ \\
\hline \multirow{6}{*}{ Yazlık } & \multirow{3}{*}{ Yerel Genotip-1 } & 0 & $223.3 \mathrm{e}$ & $19.73 \mathrm{f}$ & $11.99 \mathrm{~d}$ & $3.81 \mathrm{k}$ & $18.13 \mathrm{~g}$ & $36.16 \mathrm{~d}$ \\
\hline & & 5 & $266.9 \mathrm{de}$ & $25.06 c-f$ & $12.00 \mathrm{~cd}$ & $4.45 c$ & $19.01 \mathrm{~b}$ & $36.24 c$ \\
\hline & & 10 & $419.6 \mathrm{abc}$ & 27.96 b-e & $11.47 \mathrm{f}$ & $4.47 \mathrm{c}$ & $18.34 \mathrm{f}$ & $34.02 \mathrm{i}$ \\
\hline & \multirow{3}{*}{ Yerel Genotip-2 } & 0 & $248.8 \mathrm{de}$ & 22.50 ef & $11.88 \mathrm{e}$ & $3.98 \mathrm{~g}$ & $17.22 \mathrm{j}$ & $34.56 \mathrm{~h}$ \\
\hline & & 5 & $330.3 \mathrm{~b}-\mathrm{e}$ & 24.28 def & $11.47 \mathrm{f}$ & $4.15 \mathrm{e}$ & $18.53 \mathrm{e}$ & $36.35 b$ \\
\hline & & 10 & 387.8 bc & $28.08 \mathrm{~b}-\mathrm{e}$ & $11.09 \mathrm{~h}$ & $3.91 \mathrm{i}$ & $18.87 \mathrm{c}$ & $34.99 \mathrm{f}$ \\
\hline \multirow{2}{*}{\multicolumn{2}{|c|}{ Ekim Zamanı Ort. }} & Kışlık & $373.8 \mathrm{~A}$ & $30.72 \mathrm{~A}$ & $11.71 \mathrm{~A}$ & $4.32 \mathrm{~A}$ & $18.20 \mathrm{~B}$ & $34.85 \mathrm{~B}$ \\
\hline & & Yazlık & $313.8 \mathrm{~B}$ & $24.60 \mathrm{~B}$ & $11.65 \mathrm{~B}$ & $4.13 \mathrm{~B}$ & $18.35 \mathrm{~A}$ & $35.39 \mathrm{~A}$ \\
\hline \multirow{3}{*}{\multicolumn{2}{|c|}{ Zn Ort. }} & 0 & $259.5 \mathrm{C}$ & $24.67 \mathrm{C}$ & $12.30 \mathrm{~A}$ & $3.90 \mathrm{C}$ & $18.02 \mathrm{C}$ & $35.41 \mathrm{~B}$ \\
\hline & & 5 & 340.4 B & 27.52 B & $11.71 \mathrm{~B}$ & $4.40 \mathrm{~A}$ & $18.68 \mathrm{~A}$ & $35.60 \mathrm{~A}$ \\
\hline & & 10 & $430.0 \mathrm{~A}$ & $30.80 \mathrm{~A}$ & $11.04 \mathrm{C}$ & $4.37 \mathrm{~B}$ & $18.12 \mathrm{~B}$ & $34.34 \mathrm{C}$ \\
\hline \multirow{2}{*}{\multicolumn{2}{|c|}{ Genotip Ort. }} & Yerel Genotip-1 & $358.2 \mathrm{~A}$ & 26.26 B & $11.86 \mathrm{~A}$ & $4.18 \mathrm{~B}$ & $18.16 \mathrm{~B}$ & $34.92 \mathrm{~B}$ \\
\hline & & Yerel Genotip-2 & 328.4 B & $29.06 \mathrm{~A}$ & $11.50 \mathrm{~B}$ & $4.27 \mathrm{~A}$ & $18.38 \mathrm{~A}$ & $35.32 \mathrm{~A}$ \\
\hline
\end{tabular}

Asit deterjanda çözünmeyen lif (ADF) solüsyonunda, sülfirik asit ve cetyl trimethylammonium bromide (CTAB), hücre duvarı yapısında bulunan hemiselülozu ve proteinleri çözünür hale gelir. Geriye sadece selüloz, lignin, kutin, sindirilmeyen azot ve silika çözülmeyen maddeler olarak kalır. Nötr deterjanda çözünmeyen lif (NDF), sodium lauryl sulfate ile proteinleri, ethylediaminetetraacetic asitle (EDTA) pektini, triethylene glycol'la lif olmayan diğer maddeleri ve amilazla nişastayı yani hücre içeriğinde olan maddeleri çözünür hale getirerek, hemiselüloz, selüloz, lignin ve silis maddelerinden oluşan maddeler kalır (NFTA, 2004; Şahin ve ark., 2017). ADF ve NDF değerlerinden hayvan beslenmesinde yem kalitesini belirlemek için kullanılan oransal yem değerinin hesaplanmasında yararlanılmaktadır (Hackmann ve ark., 2008). Hayvan beslenmesinde (ruminantlar) özellikle NDF oranının yüksek; ADF oranının daha düşük olması yemin hayvan tarafından sindirilebilirlik derecesinin belirlenmesinde önemli görülmektedir. Genellikle kaliteli yemlerde ve sağlıklı bir ruminant beslenmesi için ADF oranının \%31'in altında ve NDF oranının \%25-36 arasında olması istenir (Tekce ve Gül, 2014). Çalışmamızda ADF ve NDF oranları istenilen

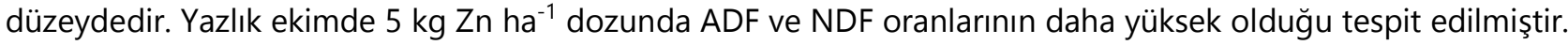

\section{Tane Mikroelement Konsantrasyonu}

Çinko dozlarının ekim zamanına bağlı olarak yulaf genotiplerinin gelişimine olumlu etkileri her iki yetiştirme dönemi boyunca gözlenmiştir. Çizelge 2'de yulafın tanesindeki mikro besin elementleri için varyans analiz sonuçları sunulmuştur. Ekim zamanı ve $\mathrm{Zn}$ dozları faktörlerinin tane $\mathrm{Zn}, \mathrm{Fe}, \mathrm{Cu}$ ve $\mathrm{Mn}$ konsantrasyonları üzerinde önemli etkisi olduğu $(p \leq 0,01)$, tanenin Fe ve $M n$ konsantrasyonunda genotipler arasındaki farkın önemli olduğu $(p \leq 0,01)$ belirlenmiştir. Ekim zamanı $\times \mathrm{Zn}$ interaksiyonu, tanenin $\mathrm{Zn}$ ve Mn konsantrasyonunu etkilerken, genotip xekim zamanı tanenin $\mathrm{Fe}, \mathrm{Cu}$ ve $\mathrm{Mn}$ konsantrasyonlarında önemli olduğu görülmüştür. Çinko dozlarının genotiplere göre etkileri, Zn ve Fe konsantrasyonu üzerinde belirlenmiştir. "Ekim zamanı $\times \mathrm{Zn} \times$ genotip" interaksiyonu Fe ve Mn konsantrasyonunda önemli olmuştur.

Yulaf genotiplerinin Zn konsantrasyonu kışık ekimde daha yüksek belirlenmiştir (Çizelge 4). Çinko dozları arttıkça Zn konsantrasyonu artmış, ancak yerel yulaf genotiplerinin $\mathrm{Zn}$ konsantrasyonu arasında fark belirlenmemiştir. Tane Zn konsantrasyonu 20,49 ile 33,0 $\mathrm{mg} \mathrm{kg}^{-1}$ arasında değişmiştir. Bu araştırmada her ne kadar kışlık ekimde yulafın ortalama Zn konsantrasyonu daha yüksek belirlenmiş olsa da, yazlık ekilen bitkilerin $\mathrm{Zn}$ konsantrasyonundaki artış, $10 \mathrm{~kg} \mathrm{Zn} \mathrm{ha}{ }^{-1}$ uygulamasında kontrol bitkilerine göre, Yerel Genotip-1'de \%61, Yerel Genotip-2'de \%41 olarak belirlenmiştir. Genotiplerin kışık ekimlerinde bu oranlar Yerel Genotip-1 için \%13, Yerel 
Genotip-2 içinse \%6 olarak hesaplanmıştır. Kışlık ekimde Zn uygulanmadan yetişen kontrol bitkilerinin tane $\mathrm{Zn}$ konsantrasyonu daha yüksek bulunmuş ve yazlık ekilen bitkilere göre toprakta daha uzun süre kalan bitkilerin, tane Zn konsantrasyonun artırdığı düşünülmüştür. Morgounov ve ark. (2007), benzer sonucu Orta Asya ülkelerinde, yazlık ve kışlık yetiştirilen buğday tanelerinin $\mathrm{Zn}$ konsantrasyonunun daha yüksek olduğunu belirlemişlerdir.

Çizelge 4. Tane mikro element içeriklerinin ekim zamanı, Zn uygulamaları ve genotiplere göre değişimi. Table 4. The change of micro element contents of oats according to sowing time, $\mathrm{Zn}$ applications and genotypes.

\begin{tabular}{|c|c|c|c|c|c|c|}
\hline \multirow[t]{2}{*}{ Ekim zamanı } & \multirow[t]{2}{*}{ Genotipler } & \multirow[t]{2}{*}{$\begin{array}{l}\text { Zn uygulaması } \\
\left(\mathrm{kg} \mathrm{ha}^{-1}\right)\end{array}$} & \multicolumn{4}{|c|}{$\begin{array}{l}\text { Yulaf tanesinin mikro element içeriği } \\
\qquad\left(\mathrm{mg} \mathrm{kg}^{-1}\right)\end{array}$} \\
\hline & & & Zn & $\mathrm{Fe}$ & $\mathrm{Cu}$ & Mn \\
\hline \multirow{6}{*}{ Kışlık } & \multirow{3}{*}{ Yerel Genotip-1 } & 0 & 27.57 & $150.43 \mathrm{fg}$ & 4.18 & 47.84 ef \\
\hline & & 5 & 28.86 & $158.57 \mathrm{efg}$ & 4.43 & $50.20 \mathrm{~d}$ \\
\hline & & 10 & 31.23 & $184.62 \mathrm{~d}$ & 4.76 & $52.23 \mathrm{c}$ \\
\hline & \multirow{3}{*}{ Yerel Genotip-2 } & 0 & 28.91 & $140.17 \mathrm{~g}$ & 3.31 & $44.97 \mathrm{~g}$ \\
\hline & & 5 & 29.24 & $167.87 \mathrm{def}$ & 3.83 & $49.69 \mathrm{~d}$ \\
\hline & & 10 & 30.68 & $173.64 \mathrm{de}$ & 4.68 & $50.30 \mathrm{~d}$ \\
\hline \multirow{6}{*}{ Yazlık } & \multirow{3}{*}{ Yerel Genotip-1 } & 0 & 20.49 & $250.86 \mathrm{ab}$ & 1.27 & $50.22 \mathrm{~d}$ \\
\hline & & 5 & 26.74 & $258.68 \mathrm{ab}$ & 2.35 & $53.24 \mathrm{c}$ \\
\hline & & 10 & 33.00 & $267.60 \mathrm{a}$ & 2.68 & $58.07 \mathrm{a}$ \\
\hline & \multirow{3}{*}{ Yerel Genotip-2 } & 0 & 21.67 & $222.05 c$ & 1.80 & $46.22 \mathrm{fg}$ \\
\hline & & 5 & 28.16 & $243.00 \mathrm{~b}$ & 2.02 & $49.06 \mathrm{de}$ \\
\hline & & 10 & 30.62 & $210.16 \mathrm{~cd}$ & 2.52 & $54.99 \mathrm{~b}$ \\
\hline \multirow{2}{*}{\multicolumn{2}{|c|}{ Ekim Zaman }} & Kışlık & $29.43 \mathrm{~A}$ & $162.55 \mathrm{~B}$ & $4.20 \mathrm{~A}$ & $49.21 \mathrm{~B}$ \\
\hline & & Yazlık & 26.78 B & $252.06 \mathrm{~A}$ & $2.11 \mathrm{~B}$ & $51.97 \mathrm{~A}$ \\
\hline \multirow[t]{3}{*}{ Zn Ort. } & & 0 & $24.66 \mathrm{C}$ & $190.88 \mathrm{C}$ & $2.64 \mathrm{C}$ & $47.32 \mathrm{C}$ \\
\hline & & 5 & $28.25 \mathrm{~B}$ & 207.03 B & $3.16 \mathrm{~B}$ & $50.55 \mathrm{~B}$ \\
\hline & & 10 & $31.41 \mathrm{~A}$ & $224.00 \mathrm{~A}$ & $3.66 \mathrm{~A}$ & $53.90 \mathrm{~A}$ \\
\hline \multirow[t]{2}{*}{ Genotip Ort. } & & Yerel Genotip-1 & 28.00 & $211.79 \mathrm{~A}$ & 3.28 & $51.97 \mathrm{~A}$ \\
\hline & & Yerel Genotip-2 & 28.21 & $202.81 \mathrm{~B}$ & 3.03 & $49.21 \mathrm{~B}$ \\
\hline
\end{tabular}

Yulaf, Zn noksanlığına makarnalık buğday kadar hassas bir tahıldır (Torun, 1997). Bu çalışmada, incelenen mineral konsantrasyonları yulaf tanelerinde, $10 \mathrm{~kg} \mathrm{Zn} \mathrm{ha}^{-1}$ uygulamasında en yüksek belirlenmiştir. Yulaf tanelerinin Zn konsantrasyonları 15,50-37,68 $\mathrm{mg} \mathrm{kg}^{-1}$ değerler arasında değiştiği bazı çalışmalarda belirtilmiştir (Biel ve ark., 2020; de Oliveira Maximino ve ark., 2020). Yılmaz ve Sonkaya (2019), yulaf tanesinin Zn

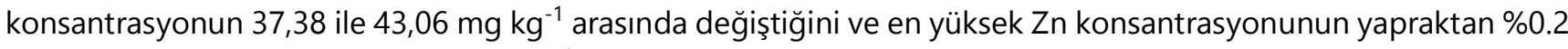
$\mathrm{Zn}$ ile beraber topraktan $2.5 \mathrm{~kg} \mathrm{Zn} \mathrm{da}^{-1}$ uygulamasıyla elde edildiğini bildirmiştir. Shivay ve ark., (2013), yulaf tohumlarına Zn ve topraktan Zn uygulanması ile, yulaf tanesinin Zn konsantrasyonunu artırdığını ve 23,8 ile 32,3 $\mathrm{mg} \mathrm{kg}^{-1}$ arasında değiştiğini, $5 \mathrm{~kg} \mathrm{Zn} \mathrm{ha}^{-1}$ toprak uygulamasınından en yüksek tane konsantrasyonu elde edildiğini belirlemiştir. Benzer şekilde diğer tahıllarla yapılan çalışmalarda da Zn uygulamasının tane Zn konsantrasyonunda artışa yol açtığı belirtilmiştir (Barut ve ark., 2017; Akgün ve ark., 2016).

Yulaf tanelerinin Zn haricindeki mikro besin elementlerinden kışlık ekimde Cu konsantrasyonu, yazlık ekimde Fe ve $\mathrm{Mn}$ konsantrasyonları yüksek belirlenmiştir. Ekim zamanının, Zn dozlarının ve genotipik farklılıkların belirlendiği Fe ve Mn konsantrasyonları (267 mg Fe kg-1 ve $58,07 \mathrm{mg} \mathrm{Mn} \mathrm{kg}^{-1}$ ) en yüksek yazlık ekimde Yerel Genotip-1'de $10 \mathrm{~kg} \mathrm{Zn} \mathrm{ha-1}$ uygulamasından elde edilmiştir. Tane Cu konsantrasyonu 1,27-4,68 $\mathrm{mg} \mathrm{kg}^{-1}$ arasında değişmiş ve kışlık ekilen Yerel Genotip-1'in 10 kg Zn ha-1 uygulamasında belirlenmiştir.

Yapılan bazı çalışmalarda yulaf tanesinin Fe içeriğinin 29,98 ile 120,40 mg kg-1 , Mn içeriğinin 25,82 ile 62,55 $\mathrm{mg} \mathrm{kg}^{-1}$ ve Cu 3,35 ile 7,64 mg kg-1 arasında değiştiği belirtilmiştir (Biel ve ark., 2020; de Oliveira Maximino ve ark., 2020). Bu araştırmada yulafın Mn ve Cu konsantrasyonları diğer araştırmalar ile uyumlu olduğu belirlenmiştir. Ancak Fe konsantrasyonu diğer çalışma sonuçlarından yüksek bulunmuştur. Bu farklııı, yetiştirme koşullarından kaynaklanmaktadır.

\section{Özellikler Arası ilişskiler}

Bin tane ağırlığı ile protein oranı, NDF ve Fe içeriği açısından negatif ve önemli korelasyon saptanırken, $\beta$ glukan, $\mathrm{Zn}$ ve $\mathrm{Cu}$ içerikleri ile verim arasında pozitif ve önemli ilişkiler belirlenmiş̧ir. Tane protein içeriğinin $\mathrm{Zn}$ uygulamasıyla azalması ve diğer özelliklerin artış göstermesi incelenen özelliklerin tümüyle, ADF ve NDF hariç, negatif korelasyon göstermesine sebep olmuştur (Çizelge 5). $\beta$-glukan oranının Zn uygulaması ile artışı nedeniyle 
pozitif ve önemli korelasyon $(p \leq 0,01)$ gözlemlenmiştir. Kepek tabakasının da azalmasına bağlı olarak özellikle 10 $\mathrm{kg} \mathrm{Zn} \mathrm{ha-1}$ uygulamasında NDF değerlerinin düşmesi bu değer ile bin tane ağırlığı arasındaki negatif ilişkiyi göstermiştir. Bin tane ağılığı ile tanedeki Zn arasındaki pozitif ilişki Zn uygulaması ile tane Zn içeriğinin endospermde arttığını göstermektedir ki bu durum beslenme açısından önemlidir. Benzer ilişki $\mathrm{Cu}$ için de söylenebilirken Fe ile negatif ilişki Fe'nin daha çok tanenin kabuk tabakasında birikme eğiliminde olduğunu göstermiştir (Peterson ve ark., 2005).

Yulaf tanelerinin mikroelement konsantrasyonları arasında yapılan ikili ilişkilerde $\mathrm{Zn}$ ile $\mathrm{Cu}$ ve $\mathrm{Mn}$ arasında pozitif, Fe ile $\mathrm{Cu}$ arasında negatif, Mn ile pozitif ilişki belirlenmiştir. Farklı bitki türleri için mikroelement içeriğindeki varyasyonun diğer araştırııılar tarafından bildirilen etkileri karmaşıktır ve hala tam olarak anlaşılmamıştır, özellikle $\mathrm{Mn}$ ile $\mathrm{Zn}$ arasındaki karşııklı ilişkiler ve bu iki elementin, $\mathrm{Cu}$ ve Fe ile olan ilişkisinde de karışıklık bulunmaktadır. Bitkilerdeki Fe'nin metabolik işlevleri, Zn arzıyla bağlantılıdır (Narwal ve Malik, 2011). Bununla birlikte, bazı araştırııılar, Fe-Zn etkileşiminin düşük konsantrasyonlarda pozitif yüksek konsantrasyonlarda ise negatif olduğunu bildirmişlerdir (Niyigaba ve ark., 2019). Li ve ark. (2019), az miktarda Zn uygulamasının Cu alımını artırdığını ancak yüksek dozlarda azalttığını bulmuşlardır. Toprakta alınabilir $\mathrm{Zn}$ bulunmasında, mısır bitkisinin $\mathrm{Mn}$ konsantrasyonunun dikkate değer ölçüde azaldığı bildirilmiştir (Adiloglu, 2006). Mn ve Fe arasındaki antagonistik etkileşimlerden dolayı, artan alınabilir toprak Mn'nın, sürgündeki Fe'i bastırdığı rapor edilmektedir (Reichman, 2002). Dokulardaki yüksek Fe iyonu konsantrasyonu, fazla $\mathrm{Cu}$ içeren toprakta yetiştirilen bitkiler için faydalıdır çünkü Fe iyonları, yapraklardaki hassas metabolik yerler için Cu iyonlarılla rekabet etmektedir (Li ve ark., 2019).

Çizelge 5. İncelenen özellikler arasındaki ilişkiler Table 5. The relationships between investigated traits.

\begin{tabular}{|c|c|c|c|c|c|c|c|c|c|}
\hline & Protein & $\beta$-Glukan & ADF & NDF & $\mathrm{Zn}$ & $\mathrm{Fe}$ & $\mathrm{Cu}$ & Mn & Verim \\
\hline Bin Tane Ağırlığı & $-0.470 * *$ & $0.547 * *$ & 0.129 & $-0.328^{*}$ & $0.629 * *$ & $-0.456^{* *}$ & $0.644^{* *}$ & 0.053 & $0.529 * *$ \\
\hline Protein & & $-0.452^{* *}$ & 0.031 & $0.356^{*}$ & $-0.434^{* *}$ & -0.271 & -0.177 & $-0.474^{* *}$ & $-0.611^{* *}$ \\
\hline$\beta$-Glukan & & & -0.079 & -0.260 & $0.422^{* *}$ & -0.116 & $0.426^{* *}$ & 0.279 & -0.112 \\
\hline ADF & & & & $0.624^{\star *}$ & 0.229 & 0.126 & -0.185 & 0.132 & -0.133 \\
\hline NDF & & & & & $-0.403^{*}$ & 0.157 & $-0.529^{* *}$ & $-0.346^{*}$ & $-0.675^{* *}$ \\
\hline Zn & & & & & & -0.148 & $0.573^{* *}$ & $0.470^{\star *}$ & $0.750^{* *}$ \\
\hline $\mathbf{F e}$ & & & & & & & $-0.729^{* *}$ & $0.641^{* *}$ & -0.112 \\
\hline $\mathrm{Cu}$ & & & & & & & & -0.042 & $0.637^{* \star}$ \\
\hline Mn & & & & & & & & & $0.496^{* *}$ \\
\hline
\end{tabular}

\section{SONUÇ}

Yüksek mineral içerikli ve özellikle $Z n$ ile zenginleştirilmiş tahıllar insan beslenmesinde önemli bir yere sahiptir. $\mathrm{Bu}$ çalışma ile kışlık olarak yetiştirilen yulafa $10 \mathrm{~kg} \mathrm{Zn} \mathrm{ha}^{-1}$ uygulamasının tanenin $\mathrm{Zn}$ ve mineral içeriğinin zenginleşmesine katkı sağladığı ortaya konulurken, yulafın tane verimini, gıda ve yem özelliklerini de olumlu etkilediği sonucuna varılmıştır. Yulaf tanelerinin kalite parametreleri ve mikroelement konsantrasyonları arasında yapılan ikili ilişkilerde tane $\mathrm{Zn}$ konsantrasyonu ile B-glukan, $\mathrm{Cu}$ ve $\mathrm{Mn}$ arasında pozitif, protein, $\mathrm{Fe}$ ile $\mathrm{Cu}$ arasında negatif ilişki belirlenmiştir. Aynı zamanda ııman iklim bölgelerinde yulafın Zn uygulamasıyla kışlık ekilmesinin verim ve Zn içeriğini artıracağı belirlenmiştir. Gelecekteki çalışmalarda, farklı yıllarda, değişik çeşit ve çevre koşullarında bu uygulamalar tekrarlanması önerilmektedir.

\section{ÇIKAR ÇATIŞMASI}

Yazarlar arasında herhangi bir çıkar çatışması bulunmamaktadır.

\section{YAZAR KATKISI}

İmren Kutlu ve Nurdilek Gülmezoğlu çalışmayı kurgulamış olup, denemeyi yürüterek verimle ilgili verileri toplamışlar ve mikroelement analizlerini yapmışlardır. Yaşar Karaduman, kalite analizlerini gerçekleştirmiştir. Verilerin istatistiksel analizlerini yaparak, sonuçların yorumlanması ve makalenin yazımına yazarlar birlikte katkı sağlamışlardır. 


\section{KAYNAKLAR}

AACCI. (2010). AACC Approved Methods (11 th ed.). American Association of Cereal Chemists International (AACC), St. Paul, $\mathrm{MN}$.

Adiloglu, S. (2006). The effect of increasing nitrogen and zinc doses on the iron, copper and the manganese contents of maize plant in calcareous and zinc deficient soils. Asian Journal of Plant Sciences, 5, 504-507.

Akgün, I., Karaman, R., Eraslan, F., \& Kaya, M. (2016). Effect of Zinc on Some Grain Quality Parameters in Bread and Durum Wheat Cultivars. Universal Journal of Agricultural Research, 4(6), 260-265.

Ames, N., Storsley, J., \& Thandapilly, S. J. (2018). Functionality of beta-glucan from oat and barley and its relation with human health. In: T. Beta \& M. E. Camire (Eds.), Cereal grain-based functional foods (pp. 141- 166). Cambridge, UK: Royal Society of Chemistry.

Anonim. (2020). World Agricultural Production USDA FAS- Circular Series WAP 6-19 June 2019. https://apps.fas. usda.gov/psdonline/app/index.html\#/app/downloads.

Bagci, A., Erdal, I., Gultekin, I., Yilmaz, A., Ekiz, H., Sade, B., Torun, M. B., \& Cakmak, I. (2007). Effect of zinc fertilization and irrigation on grain yield, zinc concentration and quality of cereal species. Zınc Crops, Improving Crop Production and Human Health, Istanbul, Turkey.

Barut, H., Şimşek, T., \& Aykanat, S. (2017). Çinko uygulamasının makarnalık buğday çeşitlerinde verim ve bazı tarımsal özellikler üzerine etkisi. Türkiye Tarımsal Araştırmalar Dergisi, 4(1), 10-23.

Biel, W., Kazimierska, K., \& Bashutska, U. (2020). Nutritional value of wheat, triticale, barley and oat grains. Acta Scientiarum Polonorum Zootechnica, 19(2), 19-28.

Bozbulut, R., \& Sanlier N. (2019). Promising effects of $\beta$-glucans on glyceamic control in diabetes. Trends in Food Science \& Technology, 83, 159-166.

Brand, T. S., Cruywagen, C. W., Brandt, D. A., Viljoen, M., \& Burger, W. W. (2003). Variation in the chemical composition, physical characteristics and energy values of cereal grains produced in the Western Cape area of South Africa. South African Journal of Animal Science, 33, 117-126.

Cakmak, I., Torun, B., Erenoğlu, B., Öztürk, L., Marschner, H., Kalayci, M., Ekiz, H., \& Yilmaz, A. (1998). Morphological and physiological differences in the response of cereals to zinc deficiency. Euphytica, 100(1-3), 349-357.

Daryanto, S., Wang, L., \& Jacinthe, P. A. (2016). Global Synthesis of Drought Effects on Maize and Wheat Production. PLOS ONE, 11(5), 1-15.

De Oliveira Maximino, J. V., Barros, L. M., Pereira, R. M., de Santi, I. I., Aranha, B. C., Busanello, C., Viena, V. E., Fretiag, R. A., Batista, B. L., de Oliveira, A. C., \& Pegoraro, C. (2020). Mineral and Fatty Acid Content Variation in White Oat Genotypes Grown in Brazil. Biological Trace Element Research, 1-13.

Eyüpoğlu, F., Kurucu, N., Talaz, S., \& Canisağ, U. (1994). Türkiye topraklarının bitkiye yarayışlı mikro element durumu. Toprak ve Gübre Araştırma Enstitüsü Yıllık Raporu.

Ghasal, P. C., Shivay, Y. S., Pooniya, V., Choudhary, M., \& Verma, R. K. (2017). Response of wheat genotypes to zinc fertilization for improving productivity and quality. Archives of Agronomy and Soil Science, 63(11), 1597-1612.

Givens, D. I., Davies, T. W., \& Laverick, R. M. (2004). Effect of variety, nitrogen fertiliser and various agronomic factors on the nutritive value of husked and naked oats grain. Animal Feed Science and Technology, 113(1-4), 169-181.

Hackmann, T. J., Sampson, J. D., \& Spain, J. N. (2008). Comparing relative feed value with degradation parameters of grass and legume forages. Journal of Animal Science, 86(9), 2344-2356.

Kahraman, T., Subaşı, A. S., Yıldız, Ö., Büyükkileci, C. \& Sanal, T. (2019). Evaluation of oat (Avena sativa L.) Genotypes for yield and some quality parameters in Trakya-Marmara Region. Turkish Journal of Agriculture - Food Science and Technology, 7, 145-151.

Kaur, S., Bhardwaj, R. D., Kapoor, R., \& Grew, S. K. (2019). Biochemical characterization of oat (Avena sativa L.) genotypes with high nutritional potential. LWT - Food Science and Technology, 110, 32-39.

Kutlu, I., \& Gulmezoglu, N. (2020). Morpho-agronomic characters of oat growing with humic acid and zinc application in different sowing times. Plant Science Today, 7(4), 594-600.

Li, Q., Chen, H. H., Qi, Y. P., Ye, X., Yang, L. T., Huang, Z. R., \& Chen, L. S. (2019). Excess copper effects on growth, uptake of water and nutrients, carbohydrates, and PSII photochemistry revealed by OJIP transients in Citrus seedlings. Environmental Science and Pollution Research, 26(29), 30188-30205. 
Liu, D. Y., Zhang, W., Pang, L. L., Zhang, Y. Q., Wang, X. Z., Liu, Y. M., \& Zou, C. Q. (2017). Effects of zinc application rate and zinc distribution relative to root distribution on grain yield and grain Zn concentration in wheat. Plant and Soil, 411(1-2), 167-178.

Mishra, L. K. (2012). Effect of phosphorus and zinc fertilization on biochemical composition of wheat. The Bioscan, 7(3), 445449.

Morgounov, A., Gómez-Becerra, H. F., Abugalieva, A., Dzhunusova, M., Yessimbekova, M., Muminjanov, H., ... \& Cakmak, I. (2007). Iron and zinc grain density in common wheat grown in Central Asia. Euphytica, 155(1), 193-203.

Mut, Z., Akay, H., \& Erbaş Köse, Ö. D. (2018). Grain yield, quality traits and grain yield stability of local oat cultivars. Journal of Soil Science and Plant Nutrition, 18(1), 269-281.

Narwal, R. P., \& Malik, R. S. (2011). Interaction of zinc with other nutrients. Indian Journal of Fertilisers, 7(10), 140-150.

NFTA, National forage testing association. (2004). http://www.foragetesting.org/. Erişim tarihi: 06.04.2021.

iyigaba, E., Twizerimana, A., Mugenzi, I., Ngnadong, W. A., Ye, Y. P., Wu, B. M., \& Hai, J. B. (2019). Winter wheat grain quality, zinc and iron concentration affected by a combined foliar spray of zinc and iron fertilizers. Agronomy, 9(5), 250.

Peterson, D. M., Wesenberg, D. M., Burrup, D. E. \& Erickson, C. A. (2005). Relationships among agronomic traits and grain composition in oat genotypes grown in different environments. Crop Science, 45(4), 1249-1255.

Reichman, S. M. (2002). The response of plants to metal toxicity: a review focusing on copper, manganese and zinc. Occasional Paper No.14. Melbourne: Australian Minerals and Energy Environment Foundation.

Rodehutscord, M., Rückert, C., Maurer, H. P., Schenkel, H., Schipprack, W. \& Knudsen, K. E. B. (2016). Variation in chemical composition and physical characteristics of cereal grains from different genotypes. Journal Archives of Animal Nutrition, 70(2), 87-107.

Shivay, Y. S., Prasad, R., \& Pal, M. (2013). Zinc fortification of oat grains through zinc fertilisation. Agricultural Research, 2(4), 375-381.

Soil Survey Laboratory Methods Manuel (2004). Soil Survey Investigation Report United States Department of Agriculture Natural Resources Conservation Service No:42, Version 4.0 November

Stevens, E. J., Armstrong, K. W., Bezar, H. J., Griffin, W. B., \& Hampton, J. G. (2004). Fodder oats, an overview. In Fodder Oats, a World Overview (eds J.M. Suttie \& S.G. Reynolds), pp. 1-9. Food and Agriculture Organization of the United Nations, Rome, Italy.

Şahin, M., Akçacık, A. G., Aydoğan, S., Hamzaoğlu, S., \& Demir, B. (2017). Yulaf (Avena sativa spp.) tanesinde bazı fiziksel özellikler ve besin bileşenlerinin tespiti. Bahri Dağdaş Hayvancılık Araştırma Dergisi, 6(1), 23-28.

Tekce, E., \& Gül, M. (2014). Ruminant beslemede NDF ve ADF'nin önemi. Atatürk Üniversitesi Veteriner Bilimleri Dergisi, 9(1), 63-73.

Torun, M. B. (1997). Değişik tahıl türlerinin ve buğday çeşitlerinin çinko eksikliğine karşı duyarlılığının araştırılması. Doktora Tezi. Çukurova Üniversitesi, Fen Bilimleri Enstitüsü, Adana.

Van Soest, P. J., Robertson, J. B., \& Lewis, B. A. (1991). Methods for dietary fiber, neutral detergent fiber, nonstarch polysaccharides in relation to animal nutrition. Journal of Dairy Science, 74, 3583-3597.

Yılmaz, N., \& Sonkaya, M. (2020). Yulafta (Avena sativa L.) çinkolu gübrelemenin verim ve verim ögeleri üzerine etkisi. Akademik Ziraat Dergisi, 9(1), 111-118. 